\title{
石灰石を触媒とする $\mathrm{NH}_{3}, \mathrm{HCN}$ の酸化時の $\mathrm{NOx}, \mathrm{N}_{2} \mathrm{O}$ の生成
}

\author{
(キーワード 石灰石, アンモニア, シアン化水素, 谼素酸化物, 亜酸化窒素, 流動層燃焼) \\ - 1992. 6.26 受理一
}

新潟大学 清水 忠明, 石須 一也, 小林 定, 鹿田 仁, 稲垣 眞

\section{1. 緒 言}

流動層燃焼 (循環流動層燃焼掞よび気泡流動層燃焼) は，炬内へ石灰石を投入することで炉内脱硫ができ， 外付けの脱硫装置が不要であることが大きな特徵であ る。しかし，炉内への石灰石供給は, $\mathrm{NOx}(\mathrm{NO}+$ $\mathrm{NO}_{2}$ ) 排出を増加させることが知られている ${ }^{12)}$ 。一方, $\mathrm{N}_{2} \mathrm{O}$ は温室効果を持つ ${ }^{3)}$ だけでなく, 成層圈に達して NO を生成し成層圈オゾンの消滅に重要な役割を果た すと言われており ${ }^{4) 5)}$, 最近では流動層燃焼置からの 排出が注目されている。流動層燃焼装置への石灰石投 入は $\mathrm{N}_{2} \mathrm{O}$ 排出を低減することがあると報告されてい $\left.ろ^{6)} \sim 10\right)$ 。

流動層燃焼装置への石灰石供給が NOx を増加する 原因について，これまで揮発分中に含まれる $\mathrm{N}$ 成分 である $\mathrm{NH}_{3}$ の酸化に対する石灰石触媒効果の検討が

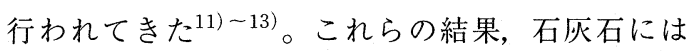
$\mathrm{NH}_{3}$ を酸化し主に NO を生成する触媒作用があること が明らかになった。しかし，石炭揮発分中には HCN も含まれており，急速昇温条件下では $\mathrm{NH}_{3} よ り$ 多量 の $\mathrm{HCN}$ が石炭から放出されることが報告されてい $ろ^{14)}$ 。 HCN 酸化に及ぼす石灰石の触媒効果について は，著者らが固定層実験を行い，1123Kに打ける主要 な酸化生成物は NO であり, 反応速度も $\mathrm{NH}_{3}$ 酸化に比 較して極めて速く, ほほ境膜物質移動律速で起こるこ とを報告した ${ }^{10)}$ 。しかし, 温度, 酸素濃度が反応速 度，生成物に及ぼ影響については，まだ報告が無い。 流動層燃焼装置への石灰石供給が $\mathrm{N}_{2} \mathrm{O}$ を低減する ことについては，石灰石が $\mathrm{N}_{2} \mathrm{O}$ の分解触媒であるこ

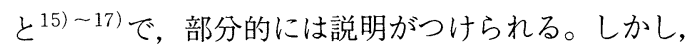

工学部化学システム工学科

新潟県新潟市五十嵐 2 の町 8050
揮発分中 $\mathrm{N}\left(\mathrm{NH}_{3}, \mathrm{HCN}\right)$ の石灰石上での酸化による $\mathrm{N}_{2} \mathrm{O}$ の生成については充分には分かっていない。 $\mathrm{NH}_{3}$ 酸化時の $\mathrm{N}_{2} \mathrm{O}$ 生成の固定層反応装置を用いたこれま での研究では, Iisa $ら^{15)}$ は $\mathrm{N}_{2} \mathrm{O}$ が生成すると報告し たが, Moritomi ら ${ }^{16)}$ および著者ら ${ }^{10)}$ は $\mathrm{N}_{2} \mathrm{O}$ が生成し ないと報告し，異なる結果が出された。石灰石が $\mathrm{N}_{2} \mathrm{O}$ の分解触媒であるので, $\mathrm{NH}_{3}$ 酸化の実験装置の出 口で観察される $\mathrm{N}_{2} \mathrm{O}$ は, $\mathrm{NH}_{3}$ から生成した $\mathrm{N}_{2} \mathrm{O}$ の一 部が装置内に共存する石灰石で分解された残余の $\mathrm{N}_{2} \mathrm{O}$ である。これまでの研究では, 共存する石灰石 による $\mathrm{N}_{2} \mathrm{O}$ 分解の影響を定量的に評価しておらず, これが前寀の報告 ${ }^{10) 15) 16)}$ 間の相違の原因である可能 性がある。よって，その影響を取り除いた真の $\mathrm{N}_{2} \mathrm{O}$ への選択率を評価する必要がある。また, $\mathrm{NH}_{3}$ 酸化時 の $\mathrm{N}_{2} \mathrm{O}$ 生成について, 温度, 酸素濃度等の影響につ いても充分明かでない。

一方, HCN は気相で酸化されると高い選択率で

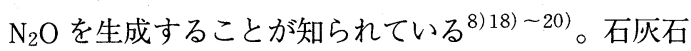
を触媒とした $\mathrm{HCN}$ 酸化時の $\mathrm{N}_{2} \mathrm{O}$ 生成については, 著 者らが1123K に扔いて $\mathrm{N}_{2} \mathrm{O}$ への選択率が 4 \% 程度と 低いことを報告した ${ }^{10)}$ 。しかし, 温度, 酸素濃度が $\mathrm{N}_{2} \mathrm{O}$ 生成に及ぼす影響については，まだ分かってい ない。流動層燃焼装置内部での石灰石の関与する $\mathrm{N}_{2} \mathrm{O}$ の生成消滅経路を明らかにするためには, 石灰 石上での $\mathrm{NH}_{3}, \mathrm{HCN}$ の酸化の研究が必要である。

本研究の目的は, $\mathrm{HCN}, \mathrm{NH}_{3}$ の酸化時の $\mathrm{NOx}, \mathrm{N}_{2} \mathrm{O}$ 生成に及ほす石灰石の触媒効果を明らかにすることで ある。このため, 固定層反応装置を用いて $\mathrm{HCN}$, $\mathrm{NH}_{3}$ の酸化を行い, 温度, 酸素濃度が, $\mathrm{HCN}, \mathrm{NH}_{3}$ の 生成物に及ぼす影響を調べた。また, $\mathrm{N}_{2} \mathrm{O}$ 分解速度 も調べ, $\mathrm{NH}_{3}, \mathrm{HCN}$ の酸化で生成した $\mathrm{N}_{2} \mathrm{O}$ が共存す 
る石灰石上で分解されることの影響を評価し，真の選 択率について論じた。

\section{2. 実 験}

実験装置を Fig.1に示す。反応管は石英製で，反応 部内径 $2 \mathrm{~cm}$ ，長さ $6 \mathrm{~cm}$ で内部に石英製焼結板を設置した ものを用いた。ガスの入口と出口は内径 $0.8 \mathrm{~cm}$ と細く することにより，ガス滞留時間を短くして気相反応の 影響を極力抑制した。入口と出口の長さはそれぞれ

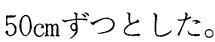

石灰石には，秩父産で粒子径 $420 ５ 90 \mu \mathrm{m}$ に粉砕し たものを用いた。石灰石の分析值を Table 1に示す。

石灰石を希釈するために平均粒子径 $0.61 \mathrm{~mm}$ の石英砂 を用いた。固定層内の温度測定には, 高純度アルミナ 保護管で保護したK熱電対を用いた。熱電対を設置し, 石英砂のみを充填した反応管で $\mathrm{NH}_{3}$ 酸化, $\mathrm{HCN}$ 酸化, $\mathrm{N}_{2} \mathrm{O}$ 分解の反応を行い, ブランクでの反応は無視で きることをあらかじめ確認した。

石灰石の焼成は $\mathrm{O}_{2}$ 雲囲気で行い, 石灰石中に存在 する有機物を燃焼除去した。これは，有機物を不活性 雲囲気で焼成するとチャーを生成する可能性があり, これが $\mathrm{HCN}$ の酸化 ${ }^{21)}, \mathrm{NH}_{3}$ の酸化 ${ }^{13) 22)}, \mathrm{N}_{2} \mathrm{O}$ の分 解 ${ }^{23)}$, NOの還元 ${ }^{24)}$ に影響を及ぼすことが考えられ るためである。石灰石中に有機物が存在することにつ いては， $\mathrm{CO}_{2}$ 中 $1123 \mathrm{~K}$ で石灰石を加熱したときに出口 ガス中に微量の CO が検出されたことから分かった。 なお，焼成終了後に $\mathrm{NH}_{3}$ 酸化， $\mathrm{N}_{2} \mathrm{O}$ 分解を行った時 の出口ガス中には CO は検出されなかったため, 有機

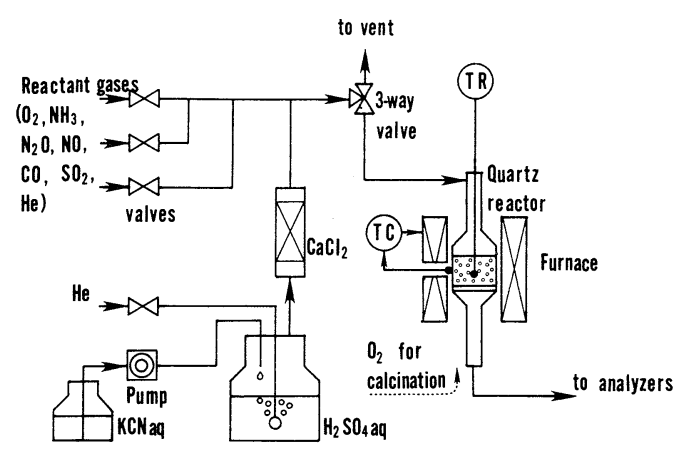

Fig. 1 Flow sheet of experimental apparatus

Table 1 Analysis of limestone

Limestone $\quad \mathrm{CaCO}_{3} \quad \mathrm{MgCO}_{3} \quad \mathrm{SiO}_{2} \quad \mathrm{~A}_{2} \mathrm{O}_{3} \quad \mathrm{Fe}_{2} \mathrm{O}_{3}$

$\begin{array}{llllll}\text { Chichibu } & 96.9 & 1.4 & 0.6 & 0.8 & 0.3\end{array}$

物は焼成中に除去されたものと考えられる。

実験手順を以下に示す。3〜 $5 \mathrm{~g}$ の石英砂を反応管の 焼結板上に投入し， $\mathrm{O}_{2}$ を反応管下部より空塔速度 $0.2 \mathrm{~m} / \mathrm{s}$ (at 1123K) で上向きに導入し石英砂を流動化 させた。この流動層中へ科量した石死石を投入して5 分間焼成した。焼成条件の差異が焼成後の石灰石反応 性に影響を及ぼさないように，焼成温度は1123K に固 定した。焼成終了後, 反応ガスを反応管上部から下向 きに導入し，固定層中で反応を行った。石疢石の焼成 方法の差異が石死石反応性に及ぼす影響を，1123K で の $\mathrm{NH}_{3}$ 酸化実験で調べた。上記の手順で行った流動 層焼成法と, 常温であらかじめ石灰石と石英砂を混合 して反応装置に充填してから固定層を $1123 \mathrm{~K}$ の電気炉 中に設置する方法(固定層焼成法)を比較した。その結 果, 流動層焼成法の反応速度定数は, 固定層焼成法の 反応速度定数の約 2 倍となった。以後では, 実際の流 動層燃焼装置の焼成条件に近いと考えられる流動層焼 成法で石灰石を焼成した。

反応ガス流量をサーマルマスフローメーターで測定 し，ニードルバルブで流量を制御した。反応ガスの希 釈にはHeを用いた。全ガス流量は，2.05 $2.10^{-3} \mathrm{~mol} / \mathrm{s}$ $(=2.75 \mathrm{Nl} / \mathrm{min})$ に固定した, すなわち，1123K で空塔 速度が $0.6 \mathrm{~m} / \mathrm{s}$ とした。

実験としては, $\mathrm{NH}_{3}$ 酸化, $\mathrm{HCN}$ 酸化, $\mathrm{N}_{2} \mathrm{O}$ 分解を 行った。 $\mathrm{NH}_{3}, \mathrm{O}_{2}, \mathrm{He}, \mathrm{N}_{2} \mathrm{O}$ は, ボンベから供給し た。 HCN 酸化実験に用いた $\mathrm{HCN}$ は, $\mathrm{KCN}$ 溶液を $\mathrm{H}_{2} \mathrm{SO}_{4}$ 溶液に連続供給し, $\mathrm{He}$ でスイープすることで 得た。この時の He スイープガスの流量は， $0.56 \times$ $10^{-3} \mathrm{~mol} / \mathrm{s}(=0.75 \mathrm{Nl} / \mathrm{min})$ に固定した。ここで得た水蒸 気を含む混合ガスを，無水 $\mathrm{CaCl}_{2}$ の充填層に流通して 乾燥させた。検知管により水蒸気濃度を測定したとこ ろ, 反応装置に供給するガス中の水蒸気濃度は約 $60 \mathrm{ppm}$ であり，本実験での HCN 濃度範囲に比較して 低いため, 石疢石上での $\mathrm{HCN}$ の加水分解 ${ }^{25)}$ による $\mathrm{HCN}$ 消費の影響は小さいものと考えられる。

実験条件を Table 2に示す。本研究では，各々の反 応速度を相対評価するため, 出口ガス中に入口ガス成 分が残存する条件で実験を行った。そのため，投入石 灰石量は実験温度によって変化させた。

排ガスの濃度測定は次のように行った。 $\mathrm{N}_{2} \mathrm{O}$ の濃 度測定には TCD 付ガスクロマトグラフを用い, $\mathrm{MS}-13 \mathrm{X}$ カラム, $\mathrm{He}$ キャリア, カラム温度 $170^{\circ} \mathrm{C}$ の条 件で測定した。 $\mathrm{N}_{2} \mathrm{O}$ の検出可能最低限界は約 $5 \mathrm{ppm}$ で あった。 $\mathrm{O}_{2}, \mathrm{~N}_{2}, \mathrm{CO}, \mathrm{CO}_{2}$ の濃度測定には TCD 付ガ スクロマトグラフを用いた。NO 濃度は化学発光式 
Table 2 Scope of the experiments

\begin{tabular}{lcccc}
\hline & \multicolumn{3}{c}{ Inlet concentrations } \\
& $\mathrm{NH}_{3}[\mathrm{ppm}]$ & $\mathrm{HCN}[\mathrm{ppm}]$ & $\mathrm{N}_{2} \mathrm{O}[\mathrm{ppm}]$ & $\mathrm{O}_{2}[\%]$ \\
\hline $\mathrm{NH}_{3}$ oxidation & $800-900$ & & $0.5-2.5$ \\
$\mathrm{HCN}$ oxidation & & $230-830$ & & $0.5-2.5$ \\
$\mathrm{~N}_{2} \mathrm{O}$ decomposition & & & $980-1011$ & $0-2.5$ \\
\hline
\end{tabular}

Temperature $=923-1123 \mathrm{~K}$

Table 3 Typical nitrogen balance for 1$) \mathrm{NH}_{3}$ oxidation $\left.(\mathrm{T}=973 \mathrm{~K}, \mathrm{~T}=1.09 \mathrm{~ms}), 2\right) \mathrm{HCN}$ oxidation ( $\mathrm{T}=$ $973 \mathrm{~K}, \mathrm{~T}=0.18 \mathrm{~ms}$ ) and 3$) \mathrm{N}_{2} \mathrm{O}$ decomposition $(\mathrm{T}=973 \mathrm{~K}, \mathrm{~T}=1.31 \mathrm{~ms}$ )

\begin{tabular}{|c|c|c|c|c|c|c|c|c|c|c|c|}
\hline & \multicolumn{5}{|c|}{ Inlet concentrations } & \multicolumn{5}{|c|}{ Outlet concentrations } & $\begin{array}{l}\text { total N } \\
\text { in outlet }\end{array}$ \\
\hline & $\begin{array}{c}\mathrm{NH}_{3} \\
{[\mathrm{ppm}]}\end{array}$ & $\begin{array}{c}\mathrm{HCN} \\
{[\mathrm{ppm}]}\end{array}$ & $\begin{array}{c}\mathrm{N}_{2} \mathrm{O} \\
{[\mathrm{ppm}]}\end{array}$ & $\begin{array}{c}\mathrm{O}_{2} \\
{[\%]}\end{array}$ & $\begin{array}{c}\mathrm{NH}_{3} \\
{[\mathrm{ppm}]}\end{array}$ & $\begin{array}{c}\mathrm{HCN} \\
{[\mathrm{ppm}]}\end{array}$ & $\begin{array}{c}\mathrm{N}_{2} \mathrm{O} \\
{[\mathrm{ppm}]}\end{array}$ & $\begin{array}{c}\mathrm{NO} \\
{[\mathrm{ppm}]}\end{array}$ & $\begin{array}{c}\mathrm{NO}_{2} \\
{[\mathrm{ppm}]}\end{array}$ & $\begin{array}{c}\mathrm{N}_{2} \\
{[\mathrm{ppm}]}\end{array}$ & {$[\mathrm{ppm}]$} \\
\hline 1) & 845 & & & 2.5 & 98 & & $\mathrm{ND}^{*}$ & 527 & trace & 109 & 843 \\
\hline 2) & & 749 & & 2.5 & 40 & 195 & 28 & 224 & trace & 132 & 778 \\
\hline 3) & & & 1011 & & & & 148 & ND & & 900 & 2096 \\
\hline
\end{tabular}

* : Not detected

NO 計を用いて測定した。 $\mathrm{NH}_{3}, \mathrm{NO}_{2}$ 濃度測定には北 川式検知管を用いた。なお， $\mathrm{NH}_{3}$ 測定用北川式検知管 を用いて， $\mathrm{He}$ で希釈した既知濃度の $\mathrm{NH}_{3}$ 混合ガスの 濃度を測定したところ，検知管の測定誤差は10\%以下 であった。ガス中 $\mathrm{HCN}$ 濃度の測定には，FID 付ガス クロマトグラフを用いた。カラム充填剤には DEGS を用い, $\mathrm{Ar}$ キャリア, カラム温度 $60^{\circ} \mathrm{C}$ 条件で測定 した。ガスクロマトグラフの較正は, $\mathrm{KCN}$ 水溶液を 塩酸と混合して酸性にした標準液をマイクロシリンジ でガスクロマトグラフに打ち込むことで行った(JIS K0109-1982)。

Table 3 に $\mathrm{NH}_{3}$ 酸化, $\mathrm{HCN}$ 酸化, $\mathrm{N}_{2} \mathrm{O}$ 分解の窒素収 支の例を示す。良好な窒素のマテリアルバランスが得 られた。表には示していないが, HCN 酸化時には生 成物中には $\mathrm{CO}, \mathrm{CO}_{2}$ が検出され, $\mathrm{CO}, \mathrm{CO}_{2}$ の生成量 の和と $\mathrm{HCN}$ の減少量はよく一致した。

\section{3. 結果と考察}

\section{$3.1 \mathrm{NH}_{3}$ 酸化}

Fig.2に $\mathrm{NH}_{3}$ 酸化で接触時間 $\tau$ が $\mathrm{NH}_{3}$ 反応率 $\left(\mathrm{X}_{\mathrm{NH}_{3}}\right)$ および消費された $\mathrm{NH}_{3}$ の $\mathrm{NO} へ$ の選択率 $(\Delta \mathrm{NO} / \Delta$ $\left.\mathrm{NH}_{3}\right)$ に及ぼす影響を示す。 $\ln \left(1-\mathrm{X}_{\mathrm{NH}_{3}}\right)$ は，接触時間 に比例した。すなわち, $\mathrm{NH}_{3}$ 酸化速度は $\mathrm{NH}_{3}$ 濃度に対 して一次であった。また, $\Delta \mathrm{NO} / \Delta \mathrm{NH}_{3}$ は接触時間

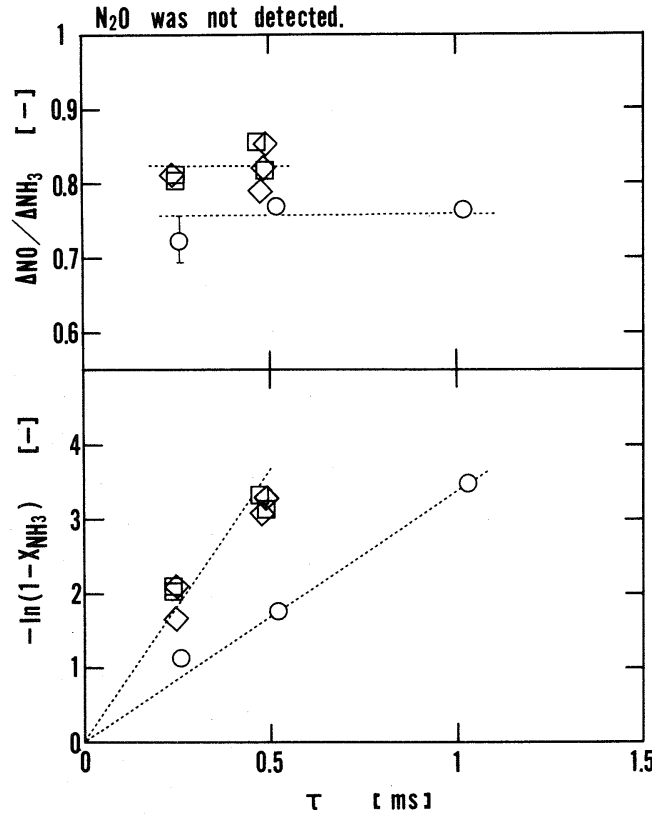

Fig. 2 Effect of contact time $\left(\tau^{*}\right)$ on $\mathrm{NH}_{3}$ conversion $\left(\mathrm{X}_{\mathrm{NH}_{3}}\right)$ and selectivity to $\mathrm{NO}(\Delta \mathrm{NO} / \Delta$ $\left.\mathrm{NH}_{3}\right)$

$\left(\mathrm{NH}_{3}=800 \sim 900 \mathrm{ppm} ; \square: 1123 \mathrm{~K}, \mathrm{O}_{2}=2.5 \%\right.$; $\diamond: 1123 \mathrm{~K}, \mathrm{O}_{2}=1.1 \% ; \quad \bigcirc: 1023 \mathrm{~K}, \mathrm{O}_{2}=2.5 \%$ ) 


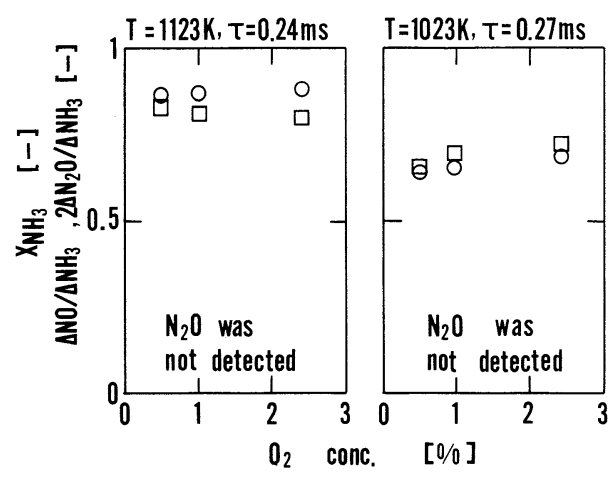

Fig. 3 Effect of oxygen concentraion on $\mathrm{NH}_{3}$ conversion and selectivities to $\mathrm{NO}$ and $\mathrm{N}_{2} \mathrm{O}$ $\left(\mathrm{NH}_{3}=800 \sim 900 \mathrm{ppm} ; \bigcirc: \mathrm{NH}_{3}\right.$ conversion ; $\square$ : selectivity to NO)

の影響を受けなかった。また， $\mathrm{N}_{2} \mathrm{O}$ は検出されな かった。

Fig. 3 に $\mathrm{NH}_{3}-\mathrm{O}_{2}$ 系における $\mathrm{O}_{2}$ 濃度が $\mathrm{NH}_{3}$ 反応率お よび $\mathrm{NH}_{3}$ の $\mathrm{NO}$ への選択率, $\mathrm{NH}_{3}$ の $\mathrm{N}_{2} \mathrm{O}$ への選択率 $\left(2 \Delta \mathrm{N}_{2} \mathrm{O} / \Delta \mathrm{NH}_{3}\right)$ に及ぼす影響を示す。本研究では 酸化速度の評価を目的としているので， $\mathrm{O}_{2}$ が存在し ない条件での実験は行わなかった。なお， $\mathrm{O}_{2}$ が存在 しない条件においては，石灰石を触媒として $\mathrm{NH}_{3} か ゙$ $\mathrm{N}_{2}$ に分解され， $\mathrm{NO}$ が生成しないことは既に報告され ている ${ }^{11) \sim 13)}$ 。 $\mathrm{NH}_{3}$ 酸化において $\Delta \mathrm{NO} / \Delta \mathrm{NH}_{3}$ は $\mathrm{O}_{2}$ 濃度の影響を受けなかった。これは平間ら ${ }^{11)}$ の結果 と一致する。また， $\mathrm{N}_{2} \mathrm{O}$ は検出されなかった。 $\mathrm{NH}_{3}$ 反 応率は $\mathrm{O}_{2}$ 濃度 $0.5 \%$ ～ $2.5 \%$ の範囲では， $\mathrm{O}_{2}$ 濃度の影響 を受けなかった，すなわち，本実験条件の範囲で $\mathrm{NH}_{3}$ 酸化速度は $\mathrm{O}_{2}$ 濃度に対して 0 次であった。

$\mathrm{NH}_{3}$ 酸化速度の $\mathrm{NH}_{3}$ 濃度, $\mathrm{O}_{2}$ 濃度への依存性の実験 結果から, $\mathrm{NH}_{3}$ 酸化が次の機構で起こっていると考え ることができる。すなわち，

1) $\mathrm{NH}_{3}$ の石灰石への吸着

2) 吸着 $\mathrm{NH}_{3}$ の $\mathrm{O}_{2}$ による酸化

ここで, $\mathrm{NH}_{3}$ の吸着が吸着 $\mathrm{NH}_{3}$ の $\mathrm{O}_{2}$ による酸化より 極めて遅い過程 $\left(\mathrm{NH}_{3}\right.$ 吸着が律速過程)であると考えれ ば，定常状態での $\mathrm{NH}_{3}$ 酸化速度は $\mathrm{O}_{2}$ 濃度に依存せず， $\mathrm{NH}_{3}$ 濃度の一次になることが説明できる。

以上の結果から, $\mathrm{NH}_{3}$ 酸化速度は $\mathrm{NH}_{3}$ 濃度に 1 次, $\mathrm{O}_{2}$ 濃度に 0 次 $\left(\mathrm{O}_{2}\right.$ 濃度 $\left.=0.5 \sim 2.5 \%\right)$ であり, $\mathrm{NH}_{3}$ 酸化 時の $\mathrm{NO}$ への選択率は接触時間， $\mathrm{O}_{2}$ 濃度の影響を受 けないことが分かった。そこで， $\mathrm{NH}_{3}$ 酸化における温 度が $\mathrm{NH}_{3}$ の $\mathrm{NO}$ への選択率に及ほす影響について，異 なった接触時間， $\mathrm{O}_{2}$ 濃度で得られたデー夕をまとめ

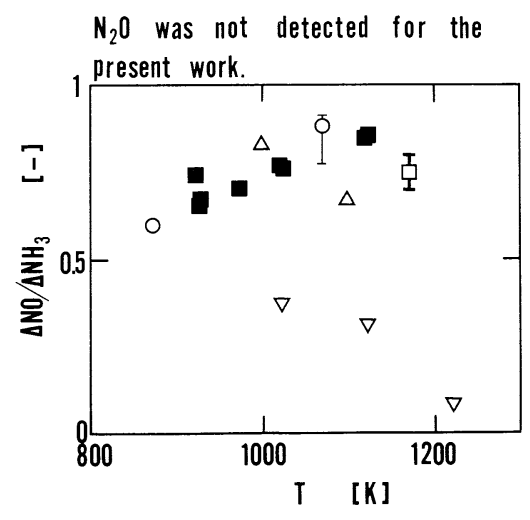

Fig. 4 Effect of temperature on selectivity to NO for $\mathrm{NH}_{3}$ oxidation

( : Present work, $\mathrm{NH}_{3}=800 \sim 900 \mathrm{ppm}, \mathrm{O}_{2}=0.5$ $\sim 2.5 \%, \quad \tau=0.23 \sim 1.14 \mathrm{~ms} ; \square$ : Hirama et al. $^{11)} ; \Delta$ : Lee et al. $^{12)}$; $\bigcirc$ : Furusawa et al. $^{13)} ; \quad \nabla$ : Iisa et al. ${ }^{15)}$ )

てFig.4に示す。温度上昇に伴い NOへの選択率がわ

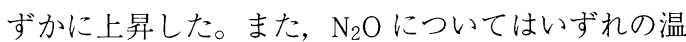
度条件でも検出されなかった。温度上昇に伴い $\mathrm{NH}_{3}$ の NOへの選択率が高くなることは, Furusawa $ら^{13)}$ の結果とほぼ同じであった。またLee $ら^{12)}$ の結果で は，温度上昇に伴い $\mathrm{NO}$ への選択率が減少したが，選 択率の值は0.68０.83であり，この值は本実験および Furusawa $ら^{13)}$ の結果とほぼ同じであった。平間ら ${ }^{11)}$ も1173K でNH酸化時の $\mathrm{NOx}$ への選択率0.7 0.8を 報告しており，本実験の結果とほぼ同様であった。し かし， $\mathrm{NH}_{3}$ 酸化時に $\mathrm{N}_{2} \mathrm{O}$ が生成したと報告した Iisa $ら^{15)}$ の結果では，温度上昇に伴い $\mathrm{NO}$ への選択率が 減少し，また，選択率の值も 0.38 以下と他の研究に比 較して極めて低い值を示した。Iisa ${ }^{15)}$ の結果と他の 結果の違いが現れた原因については，装置内に共存す る石灰石による $\mathrm{N}_{2} \mathrm{O}$ 分解効果の影響を評価した後に 論ずる。

$3.2 \mathrm{HCN}$ 酸化

ここでは， $\mathrm{HCN}-\mathrm{O}_{2}$ 系で，923K 1123K の温度範囲 での HCN 酸化の反応速度と生成物を求めた。 Table.3に HCN 酸化の生成物の例を示す。 $\mathrm{HCN}$ 酸化 の生成物の大半は $\mathrm{NO}, \mathrm{N}_{2}$ であった。生成物中に $\mathrm{N}_{2} \mathrm{O}$ が検出された。 $\mathrm{NO}_{2}$ の濃度はトレースレベルであった。 温度が1023K 以下では, 生成物の中に $\mathrm{NH}_{3}$ が検出さ れた。

Fig.5に $\mathrm{O}_{2}$ 濃度が $\mathrm{HCN}$ の反応率 $\mathrm{X}_{\mathrm{HCN}}$ および消費 された $\mathrm{HCN}$ の $\mathrm{NO}, \mathrm{N}_{2} \mathrm{O}, \mathrm{NH}_{3}$ への選択率（ $\Delta \mathrm{NO} /$ 


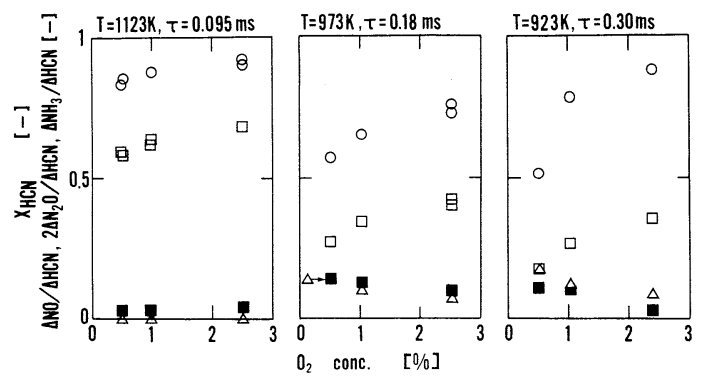

Fig. 5 Effects of oxygen concentration and temperature on conversion of $\mathrm{HCN}$ and selectivities of $\mathrm{HCN}$ to $\mathrm{NO}, \mathrm{N}_{2} \mathrm{O}$ and $\mathrm{NH}_{3}$

(inlet $\mathrm{HCN}$ concentration $=640 \sim 830 \mathrm{ppm} ; \bigcirc$ : conversion of $\mathrm{HCN} ; \square$ : selectivity to $\mathrm{NO}$; 口: selectivity to $\mathrm{N}_{2} \mathrm{O} ; \triangle$ : selectivity to $\mathrm{NH}_{3}$ )

$\left.\Delta \mathrm{HCN}, 2 \Delta \mathrm{N}_{2} \mathrm{O} / \Delta \mathrm{HCN}, \Delta \mathrm{NH}_{3} / \Delta \mathrm{HCN}\right)$ にぼす 影響を示す。本研究では酸化速度の評価を目的として いるので， $\mathrm{O}_{2}$ 濃度が 0 の条件での実験は行わなかっ た。また，温度によって反応速度が異なるため， $\mathrm{O}_{2}$ 濃度 $2.5 \%$ の条件で $\mathrm{HCN}$ 反応率が 0.75 ～ 0.9 になるよ

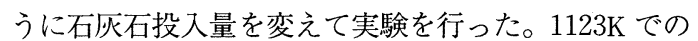
$\mathrm{HCN}$ 酸化は極めて速く, ほぼ境膜物質移動律速条件 であった ${ }^{10)}$ ので, $\mathrm{HCN}$ 酸化速度は $\mathrm{O}_{2}$ 濃度の影響を受 けなかった。しかし，973K 以下では $\mathrm{HCN}$ 酸化は反 応速度律速で起こり， $\mathrm{O}_{2}$ 濃度が高くなるにつれて $\mathrm{HCN}$ の反応率が増えた。また $973 \mathrm{~K}$ 以下では $\mathrm{O}_{2}$ 濃度 が高くなるに伴い HCN の NOへの選択率は高くなり， 一方, $\mathrm{N}_{2} \mathrm{O}, \mathrm{NH}_{3}$ への選択率は低くなった。

Fig.6に $\mathrm{HCN}$ 濃度が $\mathrm{HCN}$ の反応率 $\mathrm{X}_{\mathrm{HCN}}$ および消 費された $\mathrm{HCN}$ の $\mathrm{NO}, \mathrm{N}_{2} \mathrm{O}$ への選択率に及ぼす影響 を示す。ここでは石灰石表面の $\mathrm{HCN}$ 濃度がガス中の HCN 濃度とほぼ同じになるように反応律速条件であ る973K 以下で実験を行った。反応率は $\mathrm{HCN}$ 濃度が 高くなるに従い低くなった。すなわち, 反応速度は $\mathrm{HCN}$ 濃度に対して 1 次より低い依存性を示した。NO への選択率は $\mathrm{HCN}$ 濃度が高くなるに従い低くなった。 $\mathrm{N}_{2} \mathrm{O}$ への選択率は $\mathrm{HCN}$ 濃度が高くなるとわずかに増 加した。図には示していないが $\mathrm{NH}_{3}$ への選択率は $\mathrm{N}_{2} \mathrm{O}$ への選択率とほほ同じであり, $\mathrm{HCN}$ 濃度が高く なるとわずかに増加したが，值としては $10 \%$ 以下で あった。

なお，Fig.5とFig.6の温度 $923 \mathrm{~K}$ ，接触時間 $0.3 \mathrm{ms,}$ $\mathrm{HCN}$ 濃度600 800ppm, $\mathrm{O}_{2}$ 濃度 $2.5 \%$ の条件での $\mathrm{HCN}$ 反応率を比較すると, 両実験の結果に多少の違いが見 られるが，これはRUN の間のばらつきである。 HCN

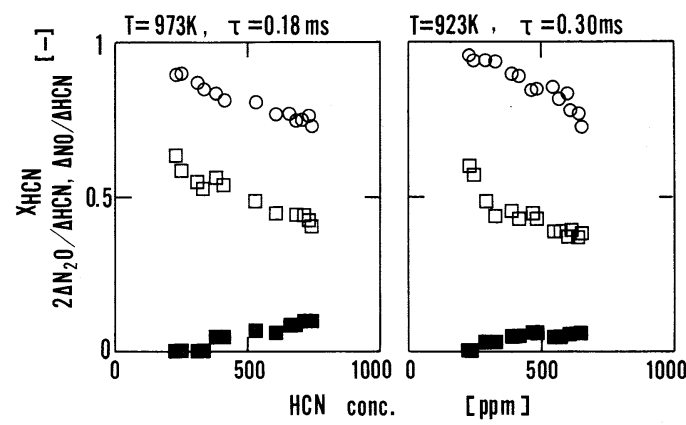

Fig. 6 Effect of inlet $\mathrm{HCN}$ concentration on conversion of $\mathrm{HCN}$ and selectivities of $\mathrm{HCN}$ to $\mathrm{NO}$ and $\mathrm{N}_{2} \mathrm{O}$

$\left(\mathrm{O}_{2}\right.$ concentration $=2.5 \% ; \quad \mathrm{O}$ : conversion of $\mathrm{HCN} ; \square$ : selectivity to NO ; $\square$ : selectivity to $\mathrm{N}_{2} \mathrm{O}$ )

酸化速度は速いために装置内に投入する石疢石量を少 なくする必要があり，それゆえ個々の石灰石粒子間の 反応性の違いが平均化されにくく, RUN ごとのばら つきが見られた。なお， $\mathrm{NH}_{3}$ 酸化， $\mathrm{N}_{2} \mathrm{O}$ 分解では，反 応速度が遅いために比較的多量の石灰石を投入したた め, 石疢石反応性のばらつきが平均化されて良好な再 現性が得られた。

本実験の結果では, $\mathrm{HCN}$ 酸化時の $\mathrm{NO}, \mathrm{N}_{2} \mathrm{O}$ への 選択率は $\mathrm{HCN}$ 濃度と $\mathrm{O}_{2}$ 濃度の両方の影響を受けた。 そのため, 選択率に対する温度の影響を独立には論ず ることはできなかった。

$\mathrm{HCN}$ 酸化時の $\mathrm{N}_{2} \mathrm{O}$ への選択率はいずれの $\mathrm{HCN}$ 濃 度， $\mathrm{O}_{2}$ 濃度，温度条件で得られた結果でも3〜10\%の 間にあった。石灰石を触媒とした気固触媒反応での $\mathrm{HCN}$ の $\mathrm{N}_{2} \mathrm{O}$ への選択率は，これまでに報告されてき た気相での酸化反応における $\mathrm{HCN}$ の $\mathrm{N}_{2} \mathrm{O}$ への選択率 $\left(1123 \mathrm{~K}\right.$ で20\%以上 $\left.{ }^{20)}\right)$ に比較して小さい值である。 $\mathrm{N}_{2} \mathrm{O}$ への選択率が, 石灰石上での気固触媒酸化時に 気相酸化より低い原因については,

1) $\mathrm{HCN}$ 酸化のメカニズムが石灰石上での気固触 媒反応と気相反応とで異なる

2）いったん生成した $\mathrm{N}_{2} \mathrm{O}$ が装置内に共存する石 灰石上で分解されたために見かけ上の $\mathrm{N}_{2} \mathrm{O}$ へ の選択率が低かった

が考えられる。これについては以下に述べる石灰石に よる $\mathrm{N}_{2} \mathrm{O}$ 分解効果についての議論の後に考察する。

$3.3 \mathrm{NH}_{3}, \mathrm{HCN}$ 酸化時の $\mathrm{N}_{2} \mathrm{O}$ の生成に及ぼす共存 石灰石による $\mathrm{N}_{2} \mathrm{O}$ 分解効果の影響の評価 以上の結果では, $\mathrm{NH}_{3}$ が酸化するときには $\mathrm{N}_{2} \mathrm{O}$ が 
生成せず， $\mathrm{HCN}$ 酸化時の $\mathrm{N}_{2} \mathrm{O}$ への選択率は3 10\%で あるとの結果が得られた。しかし，石灰石自体に $\mathrm{N}_{2} \mathrm{O}$ 分解の触媒作用があるために, $\mathrm{NH}_{3}, \mathrm{HCN}$ の酸 化でいったん生成した $\mathrm{N}_{2} \mathrm{O}$ が共存する石灰石によっ て装置内で分解され, 反応装置出口の $\mathrm{N}_{2} \mathrm{O}$ 濃度から 計算される見かけ上の $\mathrm{N}_{2} \mathrm{O}$ 選択率が極めて低く観測 された可能性が考えられる。ここでは, $\mathrm{N}_{2} \mathrm{O}$ 分解速 度を実験で求め, 先に得られた $\mathrm{NH}_{3}, \mathrm{HCN}$ 酸化の速 度から，共存石灰石による $\mathrm{N}_{2} \mathrm{O}$ 分解が見かけ上の $\mathrm{N}_{2} \mathrm{O}$ 選択率に及ぼす影響を評価した。これにより， $\mathrm{NH}_{3}, \mathrm{HCN}$ 酸化時の真の $\mathrm{N}_{2} \mathrm{O}$ への選択率について考 察した。

\subsection{1 $\mathrm{N}_{2} \mathrm{O}$ 分解に及ぼす石灰石の触媒効果}

石灰石を触媒として $\mathrm{N}_{2} \mathrm{O}$ は $\mathrm{N}_{2}$ と $\mathrm{O}_{2}$ に分解された。 Fig.7に接触時間と $\mathrm{N}_{2} \mathrm{O}$ 分解割合の関係を示す。この 反応は $\mathrm{N}_{2} \mathrm{O}$ 濃度に対して 1 次反応であった。また, $\mathrm{O}_{2}$ が存在しても反応速度が変わらないことがわかっ た。また, $\mathrm{O}_{2}$ が存在しても生成物に $\mathrm{NO}, \mathrm{NO}_{2}$ は検出 されなかった。 $\mathrm{O}_{2}$ が存在しても $\mathrm{N}_{2} \mathrm{O}$ 分解速度が变わ らないことについては, de Soete も報告している ${ }^{26)} 。$

$\mathrm{N}_{2} \mathrm{O}$ の分解過程について, de Soete は次のように $\mathrm{CaO}$ からの酸素引き抜きと再酸化があるのではない かと示唆している ${ }^{26)}$ 。

$$
\begin{aligned}
& {[\mathrm{CaO}]+\mathrm{N}_{2} \mathrm{O} \rightarrow[\mathrm{Ca}]+\mathrm{N}_{2}+\mathrm{O}_{2}} \\
& {[\mathrm{Ca}]+\mathrm{N}_{2} \mathrm{O} \rightarrow[\mathrm{CaO}]+\mathrm{N}_{2}}
\end{aligned}
$$

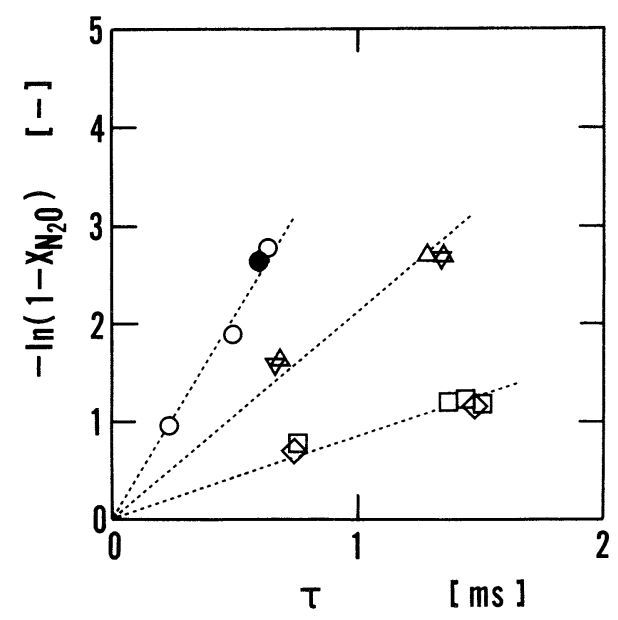

Fig. 7 Effects of contact time and oxygen concentration on $\mathrm{N}_{2} \mathrm{O}$ decomposition
(inlet $\mathrm{N}_{2} \mathrm{O}$ concentration $=980 \sim 1010 \mathrm{ppm}$;
$\mathrm{O}: 1123 \mathrm{~K}, \mathrm{O}_{2}=0 \%$
○ : $1123 \mathrm{~K}, \mathrm{O}_{2}=2.5 \%$
$\triangle: 1023 \mathrm{~K}, \mathrm{O}_{2}=0 \% ; \nabla: 1123 \mathrm{~K}, \mathrm{O}_{2}=2.5 \%$;
$\left.\square: 923 \mathrm{~K}, \mathrm{O}_{2}=0 \% ; \diamond: 923 \mathrm{~K}, \mathrm{O}_{2}=2.5 \%\right)$

ここで $[\mathrm{CaO}],[\mathrm{Ca}]$ は石灰石上の活性点と酸素が引き 抜かれた活性点をそれぞれ表す。しかし，このモデル に従えば， $\mathrm{O}_{2}$ が存在しても $\mathrm{N}_{2} \mathrm{O}$ 分解速度が変わらな いことは，[Ca]の再酸化(式2)に $\mathrm{N}_{2} \mathrm{O}$ は関与するが $\mathrm{O}_{2}$ は全く関与しないことになる。しかし $[\mathrm{Ca}]$ の酸化 に $\mathrm{N}_{2} \mathrm{O}$ は関与しても $\mathrm{O}_{2}$ は関与しないことは考えにく い。よって, $\mathrm{N}_{2} \mathrm{O}$ 分解においては de Soete モデルを 適用できないと考えられる。

$\mathrm{N}_{2} \mathrm{O}$ 分解が $\mathrm{O}_{2}$ が存在しても阻害されないことにつ いて, 著者らは次のような簡単な説明を試みる。 $\mathrm{O}_{2}$ が存在しなくとも $\mathrm{N}_{2} \mathrm{O}$ が分解することから， $\mathrm{N}_{2} \mathrm{O}$ 分 解の過程は

1） $\mathrm{N}_{2} \mathrm{O}$ の石灰石上の活性点への吸着

2) 吸着 $\mathrm{N}_{2} \mathrm{O}$ の分解

で表すことができると考えられる。 $\mathrm{O}_{2}$ が存在しても 生成物中に $\mathrm{NO}, \mathrm{NO}_{2}$ が生成されなかったことは, 吸 着 $\mathrm{N}_{2} \mathrm{O}$ と $\mathrm{O}_{2}$ が反応を起こさないことを示唆するもの である。また，石灰石上の活性点へ $\mathrm{O}_{2}$ の吸着がおき にくいと考えれば, $\mathrm{N}_{2} \mathrm{O}$ の石灰石上の活性点への吸 着は $\mathrm{O}_{2}$ の存在の影響を受けないものと考元られる。

$\mathrm{N}_{2} \mathrm{O}$ 分解反応速度を, $\mathrm{NH}_{3}, \mathrm{HCN}$ の酸化速度と比 較してFig.8に示す。 $\mathrm{NH}_{3}$ 酸化, $\mathrm{N}_{2} \mathrm{O}$ 分解は, 各々の

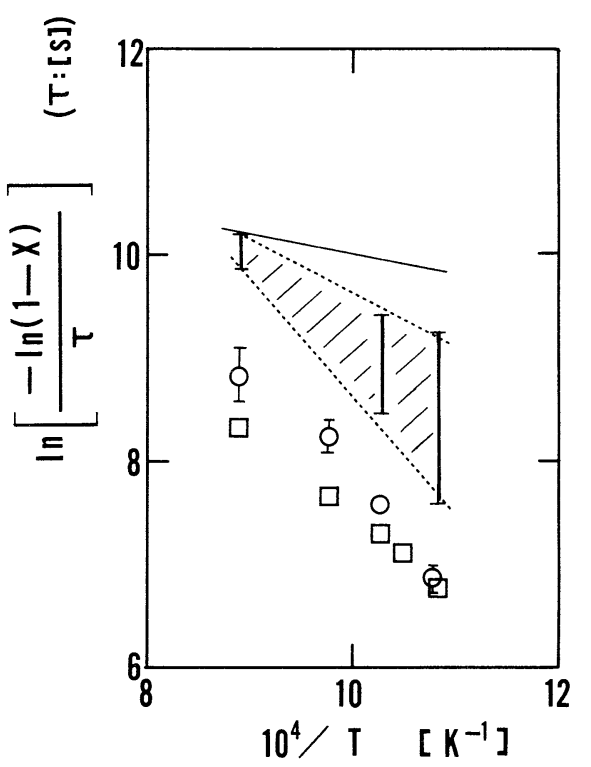

Fig. 8 Conparison of reaction rates of $\mathrm{NH}_{3}$ oxidation, $\mathrm{HCN}$ oxidation and $\mathrm{N}_{2} \mathrm{O}$ decomposition $\left(\bigcirc: \mathrm{NH}_{3}\right.$ oxidation ; $\square: \mathrm{N}_{2} \mathrm{O}$ decomposition ; hatched arae: HCN oxidation, inlet HCN concentration $=640 \sim 830 \mathrm{ppm} ;$ solid line: mass transfer limit for HCN oxidation) 
濃度に対して 1 次反応であり $\mathrm{O}_{2}$ 濃度の影響を受けな かったので, Fig.8で縦軸の $-\ln (1-\mathrm{X}) / \tau$ は, 1 次反 応速度定数を表す。一方, HCN 酸化については, $1123 \mathrm{~K}$ 近辺ではほほ境膜物質移動律速であり, また $973 \mathrm{~K}$ 以下では $\mathrm{HCN}$ 酸化速度は， $\mathrm{O}_{2}$ 濃度の影響を受 けたので，観測された $\mathrm{HCN}$ 反応率の幅を示す。本実 験の温度領域 $(923 \sim 1123 \mathrm{~K})$ では, $\mathrm{N}_{2} \mathrm{O}$ 分解は $\mathrm{HCN}$ の 酸化より遅で反応であった。 $\mathrm{NH}_{3}$ 酸化は $1123 \mathrm{~K}$ では $\mathrm{N}_{2} \mathrm{O}$ 分解より速い反応であったが，923K ではほほ同 じくらいの速度であった。

\subsection{2 $\mathrm{NH}_{3}$ 酸化に扔ける $\mathrm{N}_{2} \mathrm{O}$ への真の選択率の上 限の推定}

$\mathrm{NH}_{3}$ 酸化, $\mathrm{N}_{2} \mathrm{O}$ 分解はそれぞれ一次反応であるので, 接触時間 $\tau$ の変化に伴う, $\mathrm{N}_{2} \mathrm{O}$ 濃度 $\left[\mathrm{N}_{2} \mathrm{O}\right]$ の変化は次 式で表される。

$\left[\mathrm{N}_{2} \mathrm{O}\right]=\frac{\eta_{\mathrm{i}} \mathrm{k}_{1}}{2\left(\mathrm{k}_{2}-\mathrm{k}_{1}\right)}\left\{\exp \left(-\mathrm{k}_{1} \tau\right)-\exp \left(-\mathrm{k}_{2} \tau\right)\right\}\left[\mathrm{NH}_{3}\right]_{\mathrm{in}}$

ここで, $\mathrm{k}_{1}, \mathrm{k}_{2}, \eta_{\mathrm{i}}$ はそれぞれ, $\mathrm{NH}_{3}$ 酸化速度定数, $\mathrm{N}_{2} \mathrm{O}$ 分解速度定数, $\mathrm{NH}_{3}$ の $\mathrm{N}_{2} \overline{\mathrm{O}}$ への真の選択率であ る。これに Fig.8から求めた速度定数を代入する。こ こで計算に用いた速度定数は, $1123 \mathrm{~K}$ で $\mathrm{k}_{1}=6.5 \times 10^{3}$ $\left[\mathrm{s}^{-1}\right], \mathrm{k}_{2}=4.3 \times 10^{3}\left[\mathrm{~s}^{-1}\right], 923 \mathrm{~K}$ で $\mathrm{k}_{1}=1.0 \times 10^{3}\left[\mathrm{~s}^{-1}\right]$, $\mathrm{k}_{2}=0.9 \times 10^{3}\left[\mathrm{~s}^{-1}\right]$ である。

入口 $\mathrm{NH}_{3}$ 濃度を $900 \mathrm{ppm}$ としたときの $\tau$ と反応管出 口 $\mathrm{N}_{2} \mathrm{O}$ 濃度の関係を Fig.9に示す。ここでは, 実際 に実験を行ったての範囲で計算を行った。本研究で用 いた $\mathrm{N}_{2} \mathrm{O}$ 測定用ガスクロマトグラフの検出下限は約 $5 \mathrm{ppm}$ であったことと Fig.9に示す計算結果から, 真 の選択率が約3\%のときにリアクター出口の $\mathrm{N}_{2} \mathrm{O}$ 濃度 が検出下限になることが分かる。すなわち, 本研究で

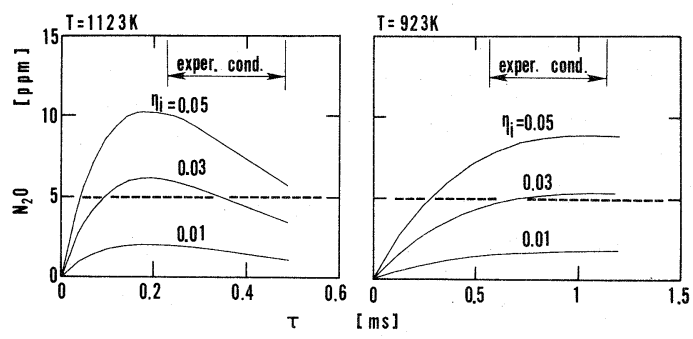

Fig. 9 Calculated change in $\mathrm{N}_{2} \mathrm{O}$ concentration with contact time $(\tau)$ for $\mathrm{NH}_{3}$ oxidation

$\left(\eta_{\mathrm{i}}\right.$ : assumed intrinsic selectivity of $\mathrm{NH}_{3}$ to $\mathrm{N}_{2} \mathrm{O}$; broken line $: \mathrm{N}_{2} \mathrm{O}$ detection limit of analyser employed for the present work; exper. cond.: range of contact time for the present work)
用いた石灰石上での $\mathrm{NH}_{3}$ 酸化における $\mathrm{N}_{2} \mathrm{O}$ への選択 率は，最大でも $3 \%$ よ低いことが分かった。なお， 著者らは $1123 \mathrm{~K}$ で石灰石上での $\mathrm{NH}_{3}-\mathrm{NO}^{-} \mathrm{O}_{2}$ 系 $\left(\mathrm{NH}_{3}\right.$ 900ppm, NO 900ppm, O 2 1.1\%) での実験を行った が,これからも $\mathrm{N}_{2} \mathrm{O}$ は検出されなかった ${ }^{10)}$ 。上と同 様の解析を行ったが, $1123 \mathrm{~K} の \mathrm{NH}_{3}-\mathrm{NO}^{-} \mathrm{O}_{2}$ 系でも $\mathrm{NH}_{3}$ の $\mathrm{N}_{2} \mathrm{O}$ への真の選択率は $3 \%$ に満たないことが分 かった。

Iisaら ${ }^{15)}$ の報告した $\mathrm{NH}_{3}$ 酸化に扔ける $\mathrm{N}_{2} \mathrm{O}$ への選 択率の值は, $1123 \mathrm{~K}$ で $\mathrm{NH}_{3}-\mathrm{O}_{2}$ 系で約 $6 \%, \mathrm{NH}_{3}-\mathrm{NO}-\mathrm{O}_{2}$ 系で約15\%であり, 本実験および Moritomi ら $^{16)}$ の結 果と大きな違いを示した。また, NOへの選択率の温 度依存性も, Iisa ${ }^{15)}$ の結果は本研究㧍よび他の研

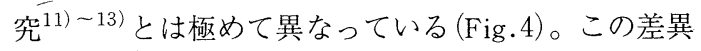
の原因としては

1）実験手法の違い

2 ) 石灰石性状の違い

が考えられる。1)については, Iisa らは本案験と同様 に石英製固定層を用いており, 気固接触は本研究と同 様と考えられる。 $\mathrm{NH}_{3}$ の存在する系で, 温度が上昇す ると $\mathrm{NO}$ 生成が減る反応としては, 気相での $\mathrm{NH}_{3}$ によ る $\mathrm{NO}$ の還元 ${ }^{27)}$ が考えられるが，石灰石を充填しな い条件では $\mathrm{N}_{2} \mathrm{O}$ が生成しなかったと Iisa らは報告し ていることから, 気相反応の寄与が大きいとは考えら れない。また, 各成分の計測法の妥当性を考えると, Iisa らの $\mathrm{NH}_{3}$ 酸化時の窒素バランスの誤差は $20 \%$ 以下 であり, Fig.4に見られる NOへの選択率の差異を説 明するには充分でない。よって $\mathrm{NH}_{3}$ 酸化時の $\mathrm{NO}$, $\mathrm{N}_{2} \mathrm{O}$ 生成の差異について, 実験装置, 計測手法の違 いの寄与がさほど大きいとは考えにくい。一方，2の 石灰石性状の違いについては, 石灰石中の微量成分, 有機物の影響が考えられる。Iisa らの用いた石灰石は, $\mathrm{NH}_{3}$ 酸化時に時間の経過と共にシンタリングが起こっ て表面積が小さくなり反応性が低くなったと報告され ているが, 本研究では活性の時間変化は見られなかっ た。この違いは, 微量成分の違いを示唆するものであ る。しかし Iisaらは使用した石灰石の成分の内, $\mathrm{CaCO}_{3} 94 \%, \mathrm{Si} 1.1 \%, \mathrm{Mg} 0.3 \%, \mathrm{Al} 0.1 \%$ の合計 $95.5 \%$ までしか示して扮らず，残り $4.5 \%$ に含まれる 微量成分については分からない。また, 本研究では石 灰石を焼成するときに有機物を除去できるように酸化 雲囲気で加熱したが， Iisa らは $\mathrm{N}_{2}$ 中で焼成を行って おり有機物の存在については論じていない。しかし微 量成分, 有機物等の存在が $\mathrm{NH}_{3}$ 酸化時の生成物に及 ぼす影響については，今後の検討課題である。 


\subsection{3 $\mathrm{HCN}$ 酸化における $\mathrm{N}_{2} \mathrm{O}$ の生成に及ぼす $\mathrm{N}_{2} \mathrm{O}$ 分解の影響}

Fig.8に示すように，本実験範囲での $\mathrm{HCN}$ の酸化 は, $\mathrm{N}_{2} \mathrm{O}$ の分解に対して2倍〜10倍速い反応である。 $\mathrm{HCN}$ 酸化実験では出口に $\mathrm{HCN}$ が残るように石灰石投 入量を少なくして実験を行った。従って, HCN 酸化 時における共存する石灰石上での $\mathrm{N}_{2} \mathrm{O}$ の分解は, 相 対的に反応速度が遅いので, 影響は極めて小さいもの と考えられる。本実験で得られた $\mathrm{HCN} の \mathrm{~N}_{2} \mathrm{O}$ への選 択率は，ほぼ真の選択率と等しいと見なしてよいと考 えられる。

3.2 で述べたように，本実験で得られた石灰石を触 媒とした $\mathrm{HCN}$ 酸化時の $\mathrm{N}_{2} \mathrm{O}$ への選択率は, 気相酸化 反応でこれまでに報告されてきた值に比較して極めて 低かった。上で議論したように，本実験条件で得られ た気固触媒反応での $\mathrm{HCN}$ の $\mathrm{N}_{2} \mathrm{O} へ$ へ選択率は，ほぼ 真の選択率と等しいと考えられる。したがって，石灰 石上での固体触媒酸化と気相酸化での $\mathrm{HCN}$ の $\mathrm{N}_{2} \mathrm{O}$ へ の選択率の違いは, 酸化反応メカニズム自体の違いに よるものと考えられる。すなわち, 気相酸化では, $\mathrm{HCN}$ から直接あるいは $\mathrm{CN}, \mathrm{HNCO}$ を経由して $\mathrm{NCO}$ が気相で生成し，NCO がNO と反応して

$$
\mathrm{NCO}+\mathrm{NO} \rightarrow \mathrm{N}_{2} \mathrm{O}+\mathrm{CO}
$$

の経路により $\mathrm{N}_{2} \mathrm{O}$ が生成されると考えられてい $3^{8) 18) ~ 20)}$ が, 一方, 気固触媒反応では固体表面への ガス成分の吸着と吸着種の反応が起こるのであり，気 相酸化反応と気固触媒反応では反応過程において生成 される中間種が全く違い，それが最終生成物の選択率 の違いになったものと考えられる。 $\mathrm{HCN}$ の石灰石上 での触媒酸化の詳細なメカニズムについては, 本研究 の結果では明らかにすることができず，今後の検討課 題として残っている。

それでもな拐，本研究の結果からは，流動層燃焼装 置への石灰石 $(\mathrm{CaO})$ 供給が $\mathrm{N}_{2} \mathrm{O}$ 排出を低減すること について，次のような定性的な説明ができる。

1) $\mathrm{CaO}$ は $\mathrm{N}_{2} \mathrm{O}$ の分解触媒である。

2 ) 石灰石が存在しない場合に $\mathrm{HCN}$ は気相で酸化 されて $\mathrm{N}_{2} \mathrm{O}$ を大量に生成するが, 石灰石が存在 すると $\mathrm{HCN}$ の一部は石灰石上で酸化されわずか しか $\mathrm{N}_{2} \mathrm{O}$ を生成しない。

しかし, 燃焼炉内での $\mathrm{N}_{2} \mathrm{O}$ の生成消滅経路の定量 的な議論については，炉内に扔ける $\mathrm{HCN}, \mathrm{NH}_{3}$ の生 成速度の分布，チャーによる $\mathrm{HCN}$ の酸化等について の知見が不十分なために，それらについての今後の検 討が必要である。

\section{4. 結 言}

固定層を用いた923〜1123K における秩父産石灰石 による $\mathrm{NH}_{3}, \mathrm{HCN}$ 酸化実験より, 次のことが明らか になった。

1） $\mathrm{NH}_{3}$ の石灰石上での酸化において，NOへの選択 率は65～80\%であり，温度上昇と共に増加した。 一方， $\mathrm{N}_{2} \mathrm{O}$ は生成物中に検出されなかった。共 存石灰石による $\mathrm{N}_{2} \mathrm{O}$ 分解を考慮に入れたとして も, $\mathrm{NH}_{3}$ の $\mathrm{N}_{2} \mathrm{O}$ への真の選択率は最大で3\%に過 ぎない。

2） $\mathrm{HCN}$ 酸化の主な生成物は $\mathrm{NO}$ と $\mathrm{N}_{2}$ であった。 $\mathrm{N}_{2} \mathrm{O}$ への選択率は3 10\%であり, 気相酸化で従 来報告されている值よりはるかに低かった。 HCN 酸化速度は HCN 濃度が高くなるにしたがい 遅くなり， $\mathrm{O}_{2}$ 濃度が高くなるにしたがい速く なった。

以上の結果から, 流動層燃焼装置への石灰石供給が $\mathrm{NOx}$ を増加させることについて, 揮発分中の $\mathrm{NH}_{3}$ の 酸化だけでなく $\mathrm{HCN}$ の酸化による NO 生成が起こっ ていることで説明できる。また，石灰石上での HCN の酸化に抢ける $\mathrm{N}_{2} \mathrm{O} へ$ へ選択率は, 気相酸化の場合 でこれまで報告された值に比較して極めて低い。流動 層燃焼装置への石灰石供給が $\mathrm{N}_{2} \mathrm{O}$ 生成を低減するこ とには，石灰石の $\mathrm{N}_{2} \mathrm{O}$ 分解作用だけでなく, $\mathrm{HCN}$ の 石灰石上での酸化による HCN 消費に伴って気相での $\mathrm{HCN}$ 酸化の割合が少なくなることも寄与していると 考えられる。

[使用記号]

$\mathrm{X}$ : conversion

$=1-\frac{\text { (outlet concentration) }}{\text { (inlet concentration) }}$

$\tau$ : contact time

$=\frac{\text { (weight of limestone) }}{\text { (density of limestone) (gas volume flow rate) }}$

$\eta_{\mathrm{i}}$ : intrinsic selectivity of $\mathrm{NH}_{3}$ to $\mathrm{N}_{2} \mathrm{O}$

(謝 辞)

本研究を行うにあたり，鉄鋼業環境保全技術開発基 金の助成ならびに出光興産株式会社の協力を得た。 $\mathrm{HCN}$ 取扱時の防災対策に関し, 三菱瓦斯化学株式会 社新潟工業所の指導を得た。ここに感謝します。また， 東京大学化学工学科定方正毅教授ならびに東北大学生 物化学工学科阿尻雅文助教授との討論に感謝します。

\section{文献}

1) Tatebayashi, J., Okada, Y., Yano, K. and Ikeda, S., Proc. 6th Int. Conf. on Fluidized Bed Com- 
bustion (Atlanta, USA), p.986 (1980)

2) Hirama, T., Takeuchi, H. and Horio, M., Proc. 9th Int. Conf. on Fluidized Bed Combustion (Boston, USA), p.898 (1987)

3 ) Ramanathan, V., Cicerone, R.J., Singh, H.B. and Kiehlm J. T., J. Geophys. Res., 90, 5547 (1985)

4 ) Pierotti, D. and Rasmussen, R. A., Geophysical Research Letters, 3, 5, 265 (1976)

5 ）島崎達夫，成層圈オゾン第2版 (東大出版会), p.44 (1989)

$6)$ Amand, L-E., Leckner, B. and Andersson, S., European Workshop on $\mathrm{N}_{2} \mathrm{O}$ Emissions LNETI /EPA/IFP (Lisbon, Portugal), p.171 (1990)

7 ) Moritomi, H., Suzuki,Y., Kido, N. and Ogisu, Y., 'Circulating Fluidized Bed Technology III' (ed by P. Basu et al.), p.399 (1991)

8 ) Hiltunen, M., Kilpinen,P., Hupa, M. and Lee, Y.Y., Proc. 11th Int. Conf. on Fluidized Bed Combustion (Montreal, Canada), p.687 (1991)

9 ) Shimizu, T., Tachiyama, Y., Kuroda, A. and Inagaki, M., Fuel, 71, p.841 (1992)

10) Shimizu, T., Tachiyama, Y., Fujita, D., Kumazawa,K., Wakayama, O., Ishizu,K., Kobayashi, S., Shikada, S. and Inagaki, M., Energy and Fuels, 6, p.753 (1992)

11）平間利昌，河内山康司，千葉忠俊，小林晴夫，燃 協誌, 61, p.268（1982）

12) Lee, Y.Y., Sekthira, A.and Wong, C.M., Proc 8th Int. Conf. on Fluidized Bed Combustion, p.1208 (1985)

13) Furusawa, T., Tsujimura, M., Yasunaga, K. and Kojima, T., Proc. 8th Int. Conf. on Fluidized Bed Combustion, p.1095 (1985)

14）神原信志, 佐藤昌弘, 宝田恭之, 中川紳好, 山本 康博, 加藤邦夫, 第29回燃料シンポジウム (京都), p.529 (1991)
15) Iisa, K., Salokoski, P. and Hupa, M., Proc. 11th Int. Conf. on Fluidized Bed Combustion (Montreal, Canada), p.1027 (1991)

16) Moritomi, H., Suzuki,Y., Kido, N. and Ogisu, Y., Proc. 11th Int. Conf. on Fluidized Bed Combustion (Montreal, Canada), p.1005 (1991)

17) Miettinen, H., Stromberg, D. and Lindquist, O., Proc. 11th Int. Conf. on Fluidized Bed Combus tion (Montreal, Canada), p.999 (1991)

18) Kramlich, J.C., Cole, J.A., McCarthy, J. M., Lanier, W. M. and McSorley, J.A., Combustion and Flame, 77, p.375 (1989)

19) Hulgaard, T., Glarborf, P. and Dam-Johansen, K., Proc. 11th Int. Conf. on Fluidized Bed Combus tion (Montreal, Canada), p.991 (1991)

20) Hulgaard, T., 'Nitrous oxide from combustion', Ph. D Thesis, Technical University of Denmark, p.104 (1991)

21）笠岡成光，笹岡英司，尾崎篤志，燃協誌， 62 , p. 53 (1983)

22) Arai, N. and Hasatani, M., Fuel, 66, p.1418 (1987)

23) de Soete, G.G., 23rd Int. Symp. on Combustion (Orleans, France), p.1257 (1990)

24）古澤健彦, 国井大蔵, 小熊昭夫, 山田信行, 化学 工学論文集, 4, p.562（1978）

25）笠岡成光，笹岡英司，尾崎篤志，燃協誌，61, p.1086 (1982)

26) de Soete, G. G., Preprints of 5th Int. Workshop on Nitrous Oxide Emissions NIRE/IFP/EPA /SCEJ (Tsukuba, Japan, July 1-3, 1992), KL-4 (1992)

27)笠岡成光, 笹岡英司, 長広盛彦, 川上喜好, 日化, 1979, p.138 (1979) 


\section{Formation of $\mathrm{NOx}$ and $\mathrm{N}_{2} \mathrm{O}$ Through Oxidation of $\mathrm{NH}_{3}$ and $\mathrm{HCN}$ Catalyzed by Limestone}

Tadaki ShImizu, Kazuya IshizU, Sadamu KobayaSHI, Shinobu ShiKada and Makoto InAGaKI

$$
\begin{gathered}
\text { (Department of Material and Chemical Engineering, } \\
\text { Niigata University }
\end{gathered}
$$

SYNOPSIS : - Catalytic effects of limestone on oxidation of $\mathrm{NH}_{3}$ and $\mathrm{HCN}$ were investigated with a quartz fixed bed reactor at temperatures between $923 \mathrm{~K}$ and $1123 \mathrm{~K}$. Limestone was found to be an active catalyst of oxidation of $\mathrm{NH}_{3}$ and $\mathrm{HCN}$. The major product of $\mathrm{NH}_{3}$ oxidation was $\mathrm{NO}$. $\mathrm{N}_{2} \mathrm{O}$ was not detected as a product of $\mathrm{NH}_{3}$ oxldation. The intrinsic selectivity of $\mathrm{NH}_{3}$ to $\mathrm{N}_{2} \mathrm{O}$ was calulated by eliminating the effect of secondary decomposition of $\mathrm{N}_{2} \mathrm{O}$ by coexisting limestone. The intrinsic selectivity of $\mathrm{NH}_{3}$ to $\mathrm{N}_{2} \mathrm{O}$ was no higher than $3 \%$. The major products of $\mathrm{HCN}$ oxidation were $\mathrm{NO}$ and $\mathrm{N}_{2}$. Selectivity of $\mathrm{HCN}$ to $\mathrm{N}_{2} \mathrm{O}$ for catalytic oxidation was 3 to $10 \%$, which are considerably lower than the reported value of selectivity for homogeneous HCN oxidation.

\section{Key Words}

Limestone, Ammonia, Hydrogen cyanide, Nitric oxide, Nitrous oxide, Fluidized bed combustion 